\title{
Palaeoenvironmental reconstruction of the Sarmatian (Middle Miocene) Central Paratethys based on palaeontological and geochemical analyses of foraminifera, ostracods, gastropods and rodents
}

\author{
EMÖKE TÓTH*, ÁGNES GÖRÖG†, CHRISTOPHE LÉCUYER $\ddagger$, PIERRE MOISSETTE $\ddagger$, \\ VINCENT BALTER \& \& MIKLÓS MONOSTORI $\dagger$ \\ *HAS-HNHM Research Group for Paleontology, H-1431 Budapest, POB 137, Hungary \\ $\dagger$ Department of Palaeontology, Eötvös University, H-1117 Budapest, Pázmány Péter sétány 1/c, Hungary \\ łUMR 5125 PEPS CNRS; Université Lyon 1, Campus de la Doua, 69622 Villeurbanne cedex, France \\ §UMR 5570 LST CNRS; Université Lyon 1, Ecole Normale Supérieure de Lyon, 45 Allée d’Italie, \\ 69364 Lyon Cedex 07, France
}

(Received 22 December 2008; accepted 27 April 2009; First published online 14 August 2009)

\begin{abstract}
Palaeoenvironmental changes in the upper Middle Miocene Central Paratethys were reconstructed by using qualitative and quantitative palaeontological analyses of foraminifera and ostracods, coupled with trace elemental $(\mathrm{Mg} / \mathrm{Ca})$ and stable isotope $\left(\delta^{18} \mathrm{O}\right.$ and $\left.\delta^{13} \mathrm{C}\right)$ analyses of their carbonate skeletons and of gastropod shells. Mean annual air temperatures were estimated using the oxygen isotope composition of contemporaneous rodent teeth. The studied aquatic fossils come from two boreholes in the Zsámbék Basin (northern central Hungary), while the terrestrial ones are from localities in NE Hungary and E Romania. In the studied Sarmatian successions, three zones could be distinguished, based on palaeontological and geochemical results. At the Badenian/Sarmatian boundary, faunal diversity decreased markedly. In the lower zone a transgressive event culminated in a seawater incursion into the semi-open basin system of the Central Paratethys. Stable bottom-water temperature $\left(\sim 15^{\circ} \mathrm{C}\right)$ and variable salinities $(20-32 \%)$ are estimated for the Early Sarmatian Sea. The faunal changes (notably a strong reduction in biodiversity) occurring at the boundary between the lower and the middle zone can be explained by a sea-level highstand with dysoxic conditions. A relative sea-level fall is documented at the end of this middle zone. After a short regressive event, a marine connection between the Paratethys and the Mediterranean was established at the beginning of the upper zone. This is indicated by an increased microfaunal diversity and the re-appearance of marine Badenian ostracods and foraminifera, which are completely absent from the older Sarmatian series. During the upper zone, the temperatures and salinities are estimated to have fluctuated from $15^{\circ} \mathrm{C}$ to $21{ }^{\circ} \mathrm{C}$ and from $15 \%$ to $43 \%$, respectively.
\end{abstract}

Keywords: ostracods, foraminifera, geochemistry, Middle Miocene, Hungary.

\section{Introduction}

The Paratethys was an epicontinental sea that developed as a relict of the ancient Tethys Ocean. It existed between Early Oligocene and late Middle Miocene times. The uplift of the Dinarids during the Middle Miocene caused a distinct change in the oceanographic and biotic evolution of the Paratethys. This geodynamic process interrupted or limited the connections between the Paratethys and the Mediterranean (Rögl \& Steininger, 1983; Rögl, 1999; Steininger \& Wessely, 2000) and was the main cause of distinct palaeobiological developments in these bioprovinces. This separate biogeographic evolution has necessitated the establishment for the Paratethys of a regional time-scale differing from the standard Mediterranean chronostratigraphic stage system (Fig. 1).

\footnotetext{
*Author for correspondence: cypridina1981@yahoo.com
}

In the Pannonian Basin of the Central Paratethys, the changes in palaeoenvironmental conditions caused by the above-mentioned tectonic instability resulted in a characteristic evolution of the flora and fauna at the base of the Sarmatian s. str. (Suess, 1866). The Sarmatian corresponds to the Late Serravallian of the Mediterranean time scale and covers the time span between 12.8 Ma and 11.5 Ma (Rögl, 1998a; Harzhauser \& Piller, 2004a). At the Badenian/Sarmatian boundary, several marine stenohaline groups of organisms disappeared (radiolarians, corals, scaphopods, cephalopods, polyplacophorans, brachiopods and echinoids), and among other groups it was mostly the euryhaline forms that persisted into the Sarmatian Central Paratethys. Currently there is still discussion focused on the environmental factors that changed in the Sarmatian sea causing the biotic modifications. The Sarmatian fauna was classically regarded as a brackish-water community (e.g. Papp, 1956; Boda, 1959; Fordinál, Zágorsek \& Zlinská, 2006; Vrsaljko et al. 2006) with 


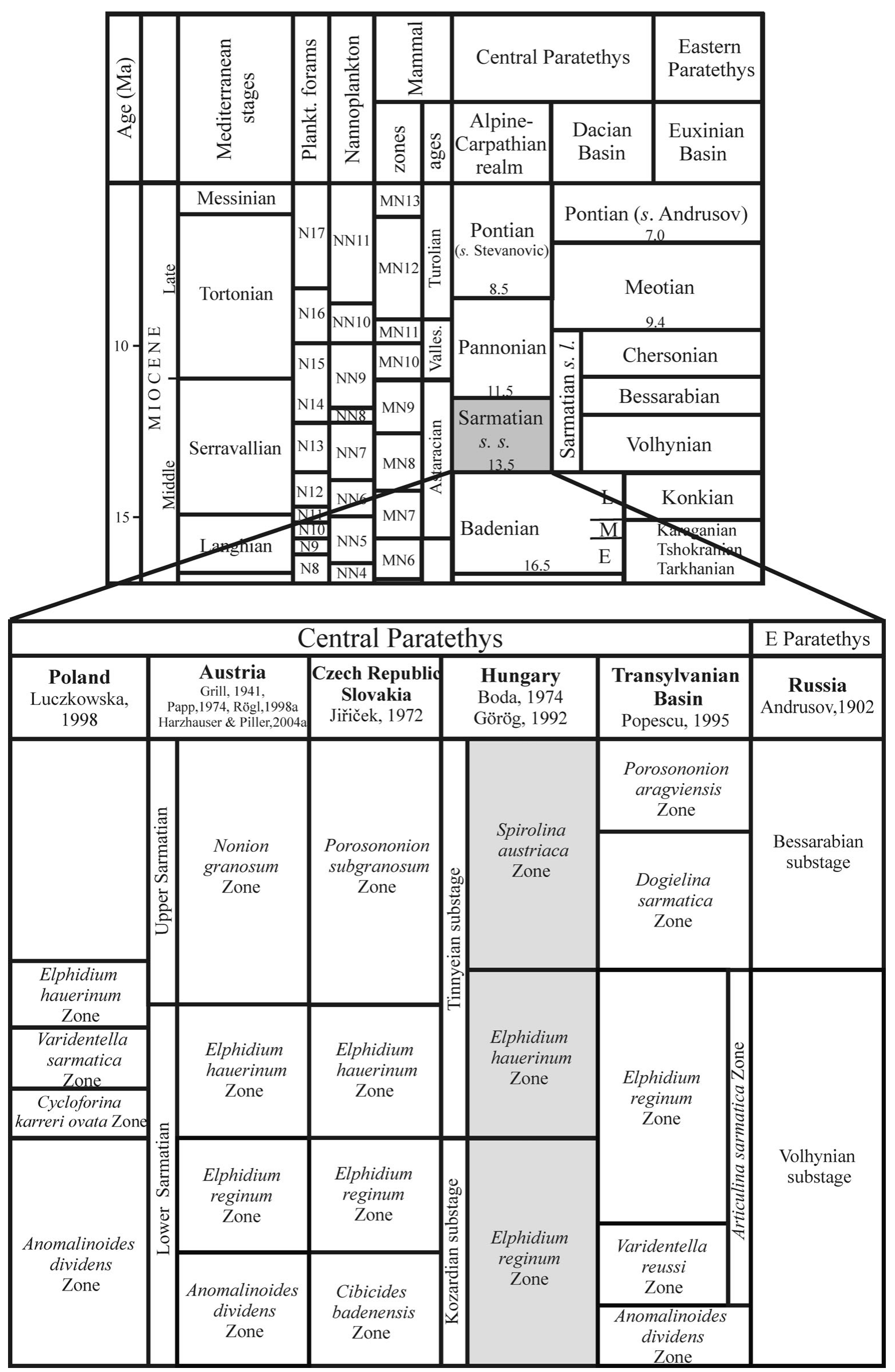

Figure 1. Stratigraphic correlation of the Mediterranean and Paratethys provinces (modified after Mátyás et al. 1996) and the Sarmatian biostratigraphic zones of the Paratethys (modified after Görög, 1992). 
gradually decreasing salinity. However, several authors have suggested recently that the Sarmatian sea was in fact more or less marine, even with hypersaline episodes, and explained the diversity fall by significant changes in water chemistry, especially high alkalinity (e.g. Pisera, 1996; Filipescu, Popa \& Wanek, 1999; Harzhauser \& Kowalke, 2002; Piller \& Harzhauser, 2005; Harzhauser, Piller \& Latal, 2007).

Published geochemical data on the Sarmatian of the Central Paratethys are scarce (Mátyás et al. 1996; Latal, Piller \& Harzhauser, 2004; Janz \& Vennemann, 2005; Harzhauser, Piller \& Latal, 2007). Moreover, these analyses were made in different outcrops of the Vienna, Pannonian and Transylvanian basins that represent only parts of the whole Sarmatian succession.

The aim of the present work is to identify the major palaeoenvironmental changes that occurred during the Sarmatian with the help of palaeontological and geochemical methods from an entire Sarmatian section. The palaeontological and geochemical investigations were carried out on skeletal material of benthic invertebrates (foraminifera, ostracods and gastropods) from two boreholes, complemented by geochemical analyses of rodent teeth. Changes in water temperature and salinity in brackish and marine environments were traced by combining $\mathrm{Mg} / \mathrm{Ca}$ and oxygen isotope ratios (Epstein et al. 1953; Dodd \& Crisp, 1982; Grossman \& Ku, 1986; Schwalb, Burns \& Kelts, 1999; Vander Putten et al. 2000; Lubinski, Polyak \& Forman, 2001; Takesue \& van Geen, 2004; Peros et al. 2007). Other environmental conditions (productivity, oxygen level in bottom waters, water depth) were reconstructed using variations of the carbon isotope ratio and qualitative and quantitative palaeontological analyses (e.g. Hartmann, 1975; Murray, 1991; van Eijden \& Ganssen, 1995; Langer, 1995).

\section{Geological setting and stratigraphy}

The Zsámbék Basin is located in the central part of the Pannonian Basin near Budapest (Fig. 2). The studied boreholes (Mány-17 and Mány-22) penetrated Sarmatian deposits that are underlain by Badenian strata of similar lithology, but with sharp changes in biofacies as attested by a strong decrease in the diversity of the macro- and microfauna. The Sarmatian succession is overlain by Pleistocene sediments (Fig. 3).

The lithology of the Sarmatian layers is heterogeneous. In the lower part, there are mainly grey to greenish-grey mollusc-bearing clays, clayey marls with intercalations of sandstones and calcareous marls. Moreover, the clayey marls contain diatomites associated with dacitic tuff and bentonite intercalations. This series can be placed in the Kozard Formation (Hámor, 1997). The upper part of the Sarmatian succession belongs to the Tinnye Formation and consists of clayey marls with carbonized plant remains, calcareous sandstones and oolitic limestones (Hámor \& Ivancsics, 1997; Cornée et al. 2009). Sandy intercalations occur

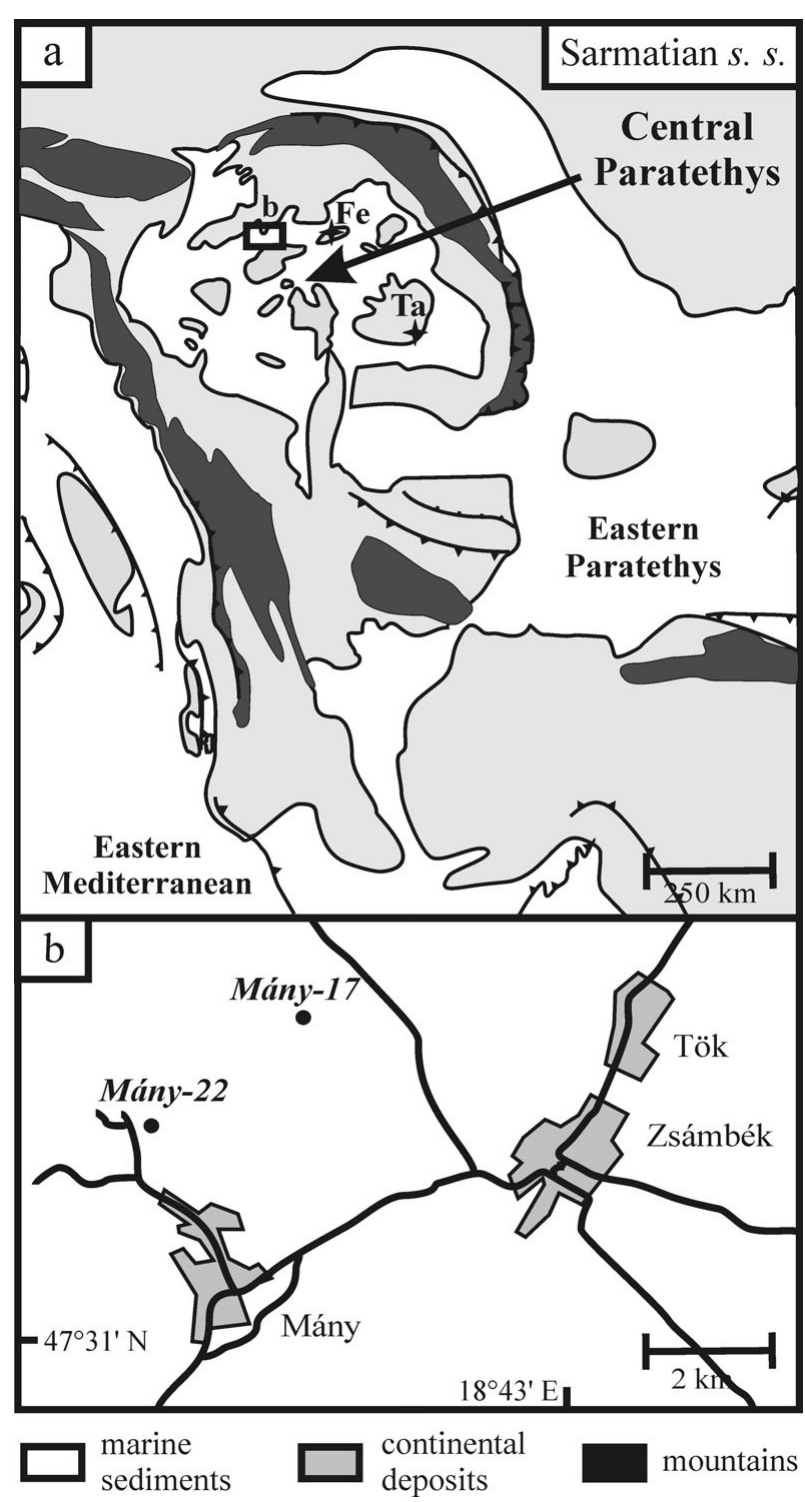

Figure 2. (a) Palaeogeographic map of the Central Paratethys (modified after Rögl, 1998b; Popov et al. 2004) with the location of the studied Zsámbék Basin; Felsőtárkány (Fe) and Tăşad (Ta) outcrops. The inset map (b) shows the position of the boreholes in the basin.

between these layers (Fig. 3). These sedimentological data indicate that during the Sarmatian this region was most likely covered by a shallow sea with numerous islands (Magyar, Geary \& Müller, 1999).

In each borehole a threefold benthic foraminiferal subdivision was proposed by Görög (1992): Elphidium reginum Zone, Elphidium hauerinum Zone and Spirolina austriaca Zone. These zones have been correlated to the regional substages based on mollusc faunas (Boda, 1974) (Fig. 1).

\section{Material and methods}

Ninety-eight samples from two boreholes (Mány-17 and Mány-22) were studied for their faunal content and fifty-two samples analysed for their trace element and stable isotope compositions. For each core sample, about $100 \mathrm{~g}$ of air-dried sediment were soaked in a 


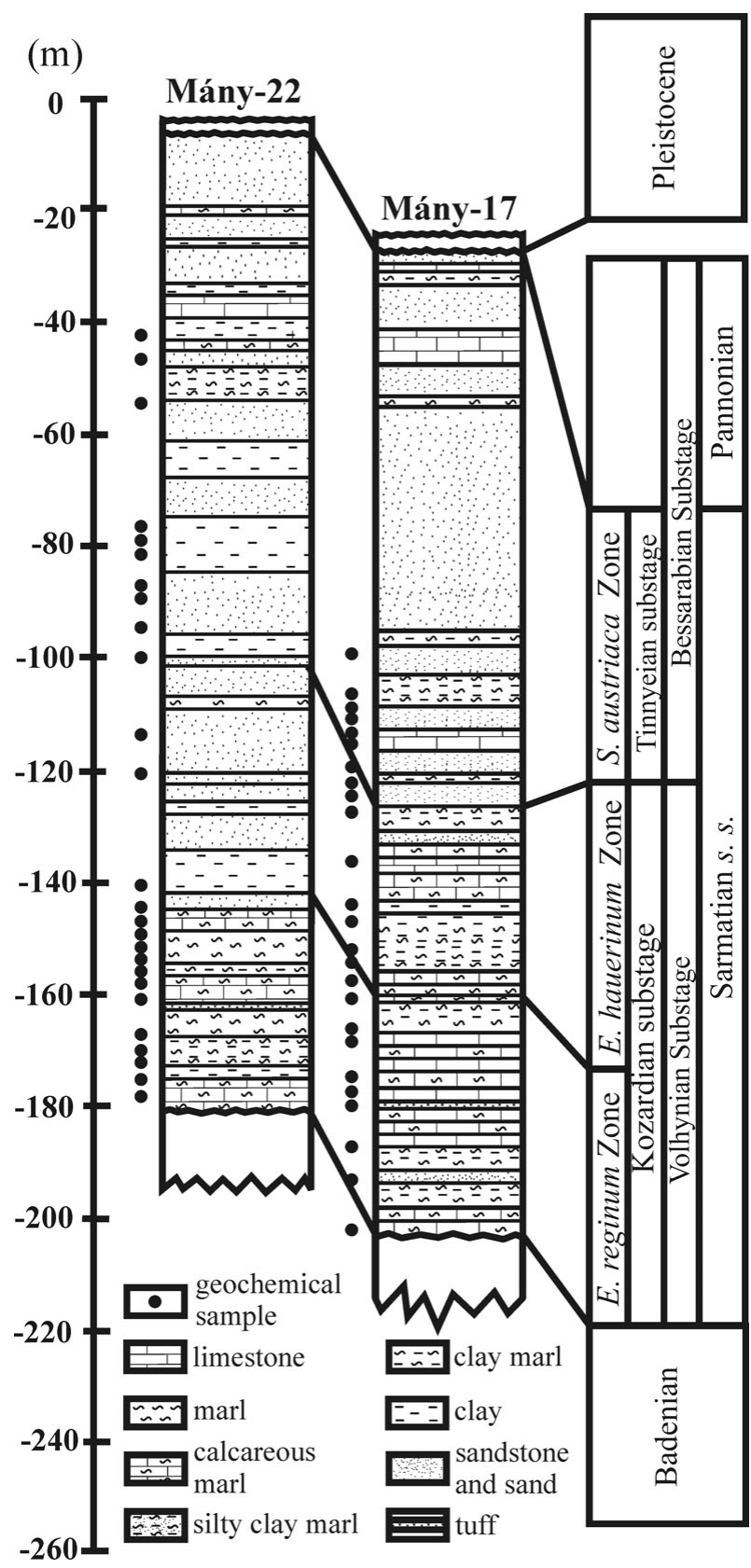

Figure 3. Lithostratigraphic logs of the studied boreholes (modified after Görög, 1992).

dilute solution of hydrogen peroxide and then washed over a column of sieves of diminishing mesh sizes to extract the carbonate skeletal fauna (foraminifera, gastropods and ostracods) for both investigations.

Phosphatic rodent teeth were extracted from the Upper Sarmatian non-marine clay series of Gödür-kert (3/2 sample) and Felnémet roadcut (2/3, 2/7 samples) at Felsôtárkány (NE Hungary) and from the Lower Sarmatian green clay beds of Tăşad (Ta sample; E Romania; Fig. 2) (Hír et al. 2001; Hír, 2004).

\section{3.a. Palaeontological analyses}

The taxonomic study and quantitative analysis of the benthic foraminifera were made by Görög (1992). A detailed systematic description of the ostracod fauna from the same boreholes was prepared by Tóth (2008). In this paper, we have attempted a simultaneous palaeoecological interpretation of the foraminifera and ostracods based on qualitative (taxonomic composition of the fauna) and quantitative analyses. These microfaunas are characterized by the total diversity and the Jaccard's Coefficient of Community $(R)$ emend. Ruban \& Tyszka (2005), which are two indices of changes in faunal associations (Fig. 4). Total diversity means the total number of species. $R$ reflects the similarity of two fossil assemblages from different stratigraphic intervals: $R=\mathrm{C} /\left[\left(N_{1}+N_{2}\right)-C\right]$, where $C$ is the number of taxa present in both intervals, and $N_{1}$ and $N_{2}$ are the number of taxa in the lower and upper interval, respectively.

\section{3.b. Geochemical analyses}

In all samples, the calcitic shells of foraminifera and ostracods and aragonitic shells of gastropods preserved their original crystal structure (proved by X-ray diffraction technique) (Fig. 5). The shells were cleaned three times with deionized water in an ultrasonic bath to remove the sedimentary matrix. The resulting sediment-free shells were then picked under a stereomicroscope. Oxygen and carbon stable isotope compositions and trace element compositions were measured on bulk carbonate skeletons of gastropods because of the small size of their shells, as well as the relatively low intrashell variability of the studied taxa (Latal, Piller \& Harzhauser, 2004). Whole gastropod shells were therefore crushed in an agate mortar until a fine powder was obtained.

\section{3.b.1. Trace elements in carbonates}

Trace element analyses have been performed on twenty-three samples of gastropods (Mohrensternia inflata, Granulolabium bicinctum, Potamides disjunctus, Hydrobia hoernesi and Cerithium rubiginosum; Fig. 6; see online Appendix Table A1 at http://journals.cambridge.org/geo). $\mathrm{Mg}$ and $\mathrm{Ca}$ concentrations in about $5 \mathrm{mg}$ of powdered samples were measured by ICP-MS using the masses ${ }^{24} \mathrm{Mg}$ and ${ }^{44} \mathrm{Ca}$. Indium was used as an internal standard. Distilled $\mathrm{HNO}_{3}(4.5 \mathrm{M})$ was used for the digestion of these calcium carbonate shells. Overall reproducibility is estimated at $\pm 2 \%(1 \sigma)$ for $\mathrm{Mg} / \mathrm{Ca}$ measurements.

\section{3.b.2. Carbon and oxygen isotope compositions of carbonates}

One hundred and seven carbon and oxygen stable isotope compositions were determined for four species of foraminifera (Elphidium aculeatum, E. hauerinum, E. macellum and Ammonia beccarii; Fig. 7), two ostracod species (Aurila mehesi and A. notata; Fig. 7) and five gastropod species (Mohrensternia angulata, Granulolabium bicinctum, Potamides disjunctus, $\mathrm{Hy}$ drobia hoernesi and Cerithium rubiginosum; Fig. 6). Stable isotope ratios were determined by using an 

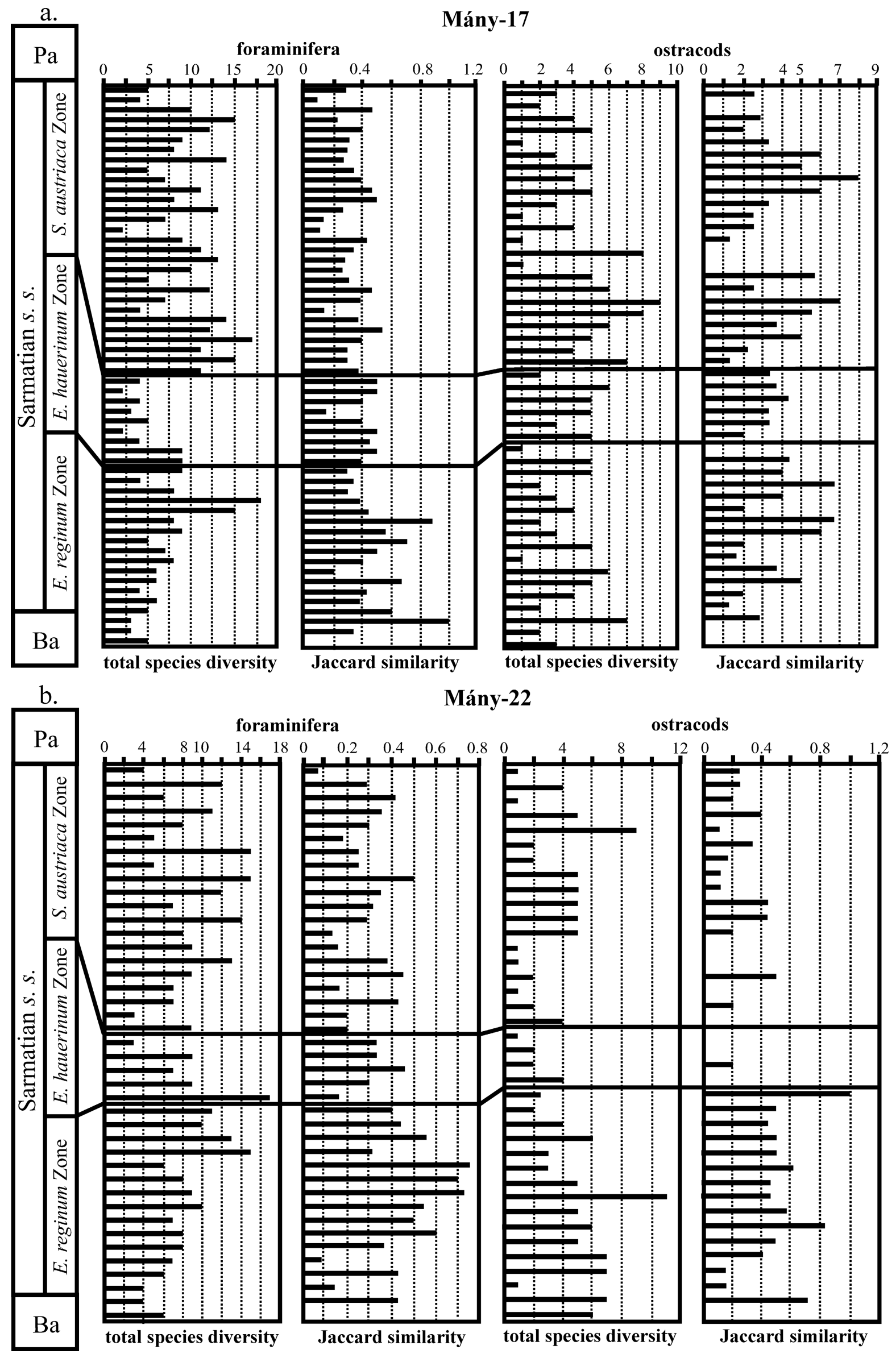

Figure 4. Variations in foraminifer and ostracod diversity and Jaccard's index in the Zsámbék Basin during the Sarmatian. Ba Badenian; Pa - Pannonian. 


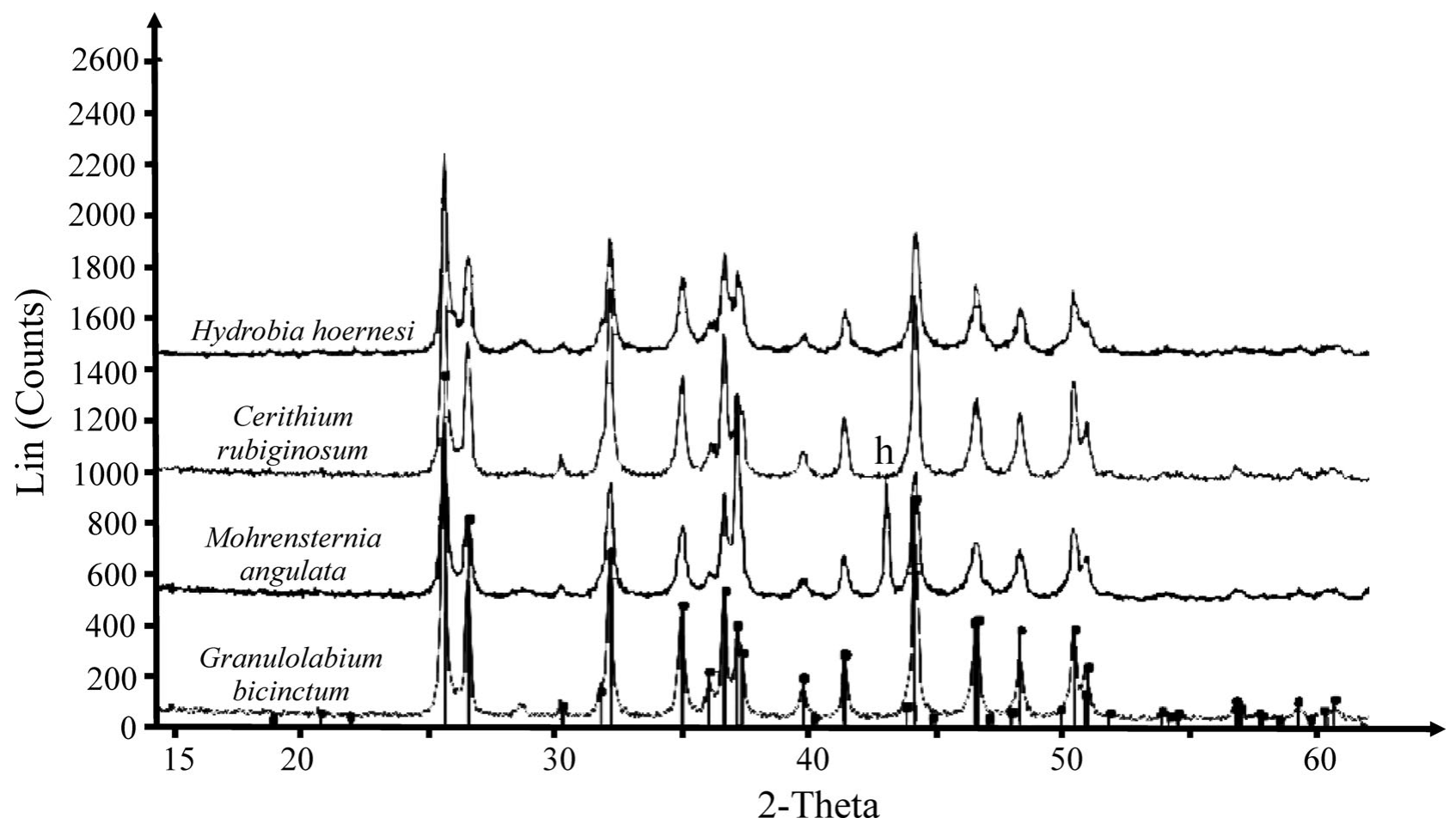

Figure 5. X-ray diffractogram of shells of gastropod species used for geochemical analyses. All peaks of aragonite except peak of aluminium (h) deriving from the sample holder.

auto sampler MultiPrep ${ }^{\mathrm{TM}}$ system coupled to a dualinlet GV Isoprime ${ }^{\mathrm{TM}}$ isotope ratio mass spectrometer (IRMS). For each sample, about $300 \mu \mathrm{g}$ of calcium carbonate were reacted with oversaturated phosphoric acid at $90{ }^{\circ} \mathrm{C}$ (7-14 valves of Aurila, 15-20 shells of Elphidium and 28-44 shells of Ammonia were used). Isotopic compositions are quoted in $\delta$-notation in per mille relative to $\mathrm{V}-\mathrm{PDB}$ (see online Appendix Tables A1, A2). All sample measurements were triplicated and adjusted to the international reference NIST NBS19. External reproducibility was $\pm 0.1 \%$ for $\delta^{18} \mathrm{O}$ values and \pm 0.05 for $\delta^{13} \mathrm{C}$ values $(1 \sigma)$.

\section{3.b.3. Oxygen isotope compositions of phosphates}

Four oxygen isotope compositions were measured on the incisors of rodents (Table 1). Three or four teeth were used for each measurement. Phosphate from biogenic apatites was isolated as $\mathrm{Ag}_{3} \mathrm{PO}_{4}$ crystals, following a protocol originally worked out by Crowson et al. (1991) and slightly modified by Lécuyer et al. (1993). The ${ }^{18} \mathrm{O} /{ }^{16} \mathrm{O}$ ratios are measured after reaction of silver phosphate with graphite to form $\mathrm{CO}_{2}\left(\mathrm{O}^{\prime} \mathrm{Neil}\right.$ et al. 1994; Lécuyer et al. 1998). $\mathrm{CO}_{2}$ samples were analysed at the University of Lyon with a GV PRISM II stable isotope ratio mass spectrometer using dual inlet systems with automated cold fingers. Isotopic compositions are quoted in the standard $\delta$ notation relative to V-SMOW. The reproducibility of measurements carried out on tooth enamel samples is better than $0.2 \% 0(1 \sigma)$. Silver phosphate precipitated from standard NBS120c (natural Miocene phosphorite from Florida) was repeatedly analysed $\left(\delta^{18} \mathrm{O}=21.75\right.$
Table 1. Phosphate oxygen isotope compositions of rodent teeth $\left(\delta^{18} \mathrm{O}_{\mathrm{p}}\right)$ and estimates of local meteoric water composition and air temperature

\begin{tabular}{lcccr}
\hline Sample & Age & $\begin{array}{c}\delta^{18} \mathrm{O}_{\mathrm{p}}(\% \mathrm{o}, \\
\mathrm{V}-\mathrm{SMOW})\end{array}$ & $\begin{array}{c}\delta^{18} \mathrm{O}_{\mathrm{w}}{ }^{*} \\
(\% \mathrm{\%})\end{array}$ & $\begin{array}{c}T^{* *} \\
\left({ }^{\circ} \mathrm{C}\right)\end{array}$ \\
\hline Felsőtárkány 3/2 & Upper Sarmatian & 19.8 & -2.2 & 21 \\
Felsőtárkány 2/3 & Upper Sarmatian & 17.7 & -5.8 & 15 \\
Felsőtárkány 2/7 & Upper Sarmatian & 17.8 & -5.5 & 15 \\
Tăşad & Lower Sarmatian & 17.7 & -5.7 & 15 \\
\hline
\end{tabular}

*Annual mean oxygen isotope compositions of meteoric waters were calculated using the fractionation equation established by Navarro et al. (2004):

$$
\delta^{18} \mathrm{O}_{\mathrm{p}}=20.98( \pm 0.59)+0.572( \pm 0.065)^{*} \delta^{18} \mathrm{O}_{\mathrm{w}}
$$

** Annual mean air temperatures were estimated according to von Grafenstein et al.'s (1996) equation:

$$
\delta^{18} \mathrm{O}_{\mathrm{w}}=0.58^{*} \mathrm{~T}-14.48
$$

$\pm 0.20 ; \mathrm{n}=4$ ) along with the silver phosphate samples derived from the rodent teeth.

\section{Palaeontological results (see online Appendix} Tables A1, A2)

The palaeoecological study of the foraminifera is mainly adapted from Görög (1992). These results are complemented with and compared to the interpretation of the ostracod fauna. The Sarmatian beds from the studied boreholes contain a great abundance of well-preserved ostracods that most likely represents the original biocenosis because juvenile/small and adult/large forms coexist, indicating that no sorting 


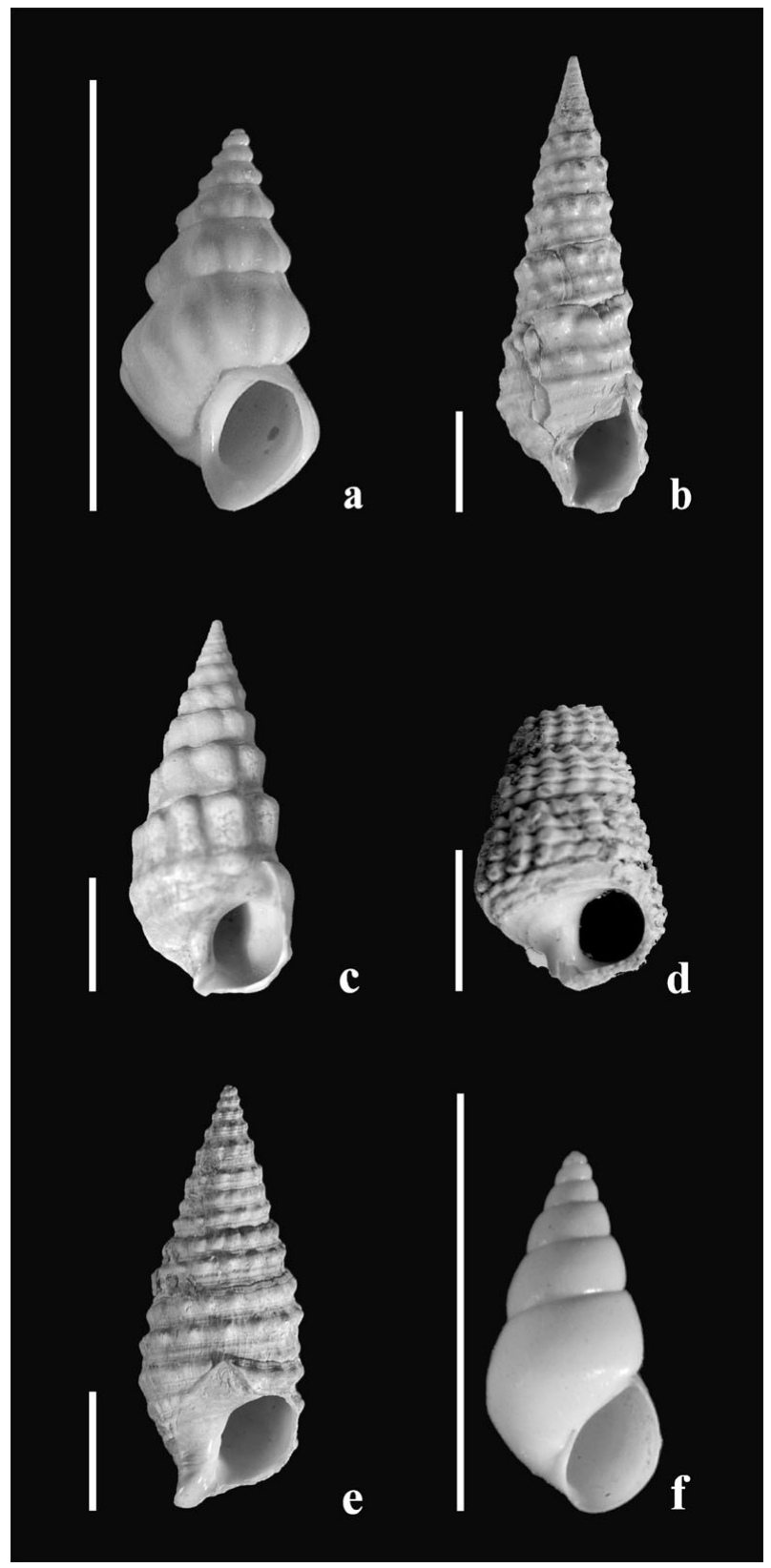

Figure 6. Gastropod species used for geochemical analyses. Scale bar $=5 \mathrm{~mm}$. (a) Mohrensternia angulata (Eichwald). Mány-17 borehole, depth 144.6-147 m. (b) Granulolabium bicinctum (Brocchi). Mány-17 borehole, depth 92-92.3 m. (c) Granulolabium bicinctum (Brocchi). Mány-17 borehole, depth 128.6-130 m. (d) Potamides sp. Mány-17 borehole, depth 144.1-147 m. (e) Cerithium rubiginosum Eichwald. Mány-17 borehole, depth 111-111.2 m. (f) Hydrobia hoernesi Friedberg. Mány-17 borehole, depth 81.5-85.3 m.

occurred. The low carapace/valve ratio reflects a slow sedimentation rate (Oertli, 1971). Ostracods have already been applied successfully to palaeoecological reconstructions because they occur in all aquatic environments and are very sensitive to small changes in salinity (e.g. Morkhoven, 1962; Hartmann, 1975).

\section{4.a. Elphidium reginum Zone}

At the Badenian/Sarmatian boundary, the faunal diversity strongly decreased, accompanied by a sharp species turnover. Among more than one hundred species of Badenian ostracods, only seven survived into the Sarmatian (Callistocythere egregia, Hemicyprideis dacica dacica, Hemicytheria omphalodes, Senesia vadaszi, Loxoconcha ex. gr. punctatella, Loxocorniculum hastatum and Xestoleberis fuscata) (Tóth, 2008). Only two Mediterranean species occur in the Sarmatian fauna of the Zsámbék Basin, while several endemic species appeared (Amnicythere sp., A. tenuis, Callistocythere incostata, Cnestocythere aff. truncata, Euxinocythere praebosqueti, E. diafana, E. naca, Cytheridea hungarica, Miocyprideis sarmatica, Aurila merita, A. mehesi, Loxoconcha kochi and $L$. porosa). This faunal pattern argues in favour of a very limited connection between the Paratethys and the Mediterranean at the Badenian/Sarmatian boundary. In the Elphidium reginum Zone, Aurila mehesi, Cytheridea hungarica and Senesia vadaszi are the most common among the fifteen species documented. The abundance of Aurila mehesi and Cytheridea hungarica probably depends on the substrate lithology, the latter genus preferring sandy bottoms (Hartmann, 1975). The ostracod community indicates epineritic, infralittoral to upper circalittoral zones with wellventilated waters at depths less than $80 \mathrm{~m}$ (Hartmann, 1975). Modern Xestoleberis, Hemicytheria, Aurila and Loxoconcha species live mainly on algae or seagrasses in the littoral zone (Puri, Bonaduce \& Gervasio, 1969). Many ostracod specimens show a significant reduction of ornamentation that also suggests a stressed environment (Hartmann, 1975).

Among the foraminifera, the abundance of Hauerinidae in the lowermost strata indicates shallow, warmtemperate waters. Above the Hauerina-rich layers, the dominance of large elphidiids points to deeper-water settings (Görög, 1992). The specimens of Cibicides that mainly lived attached on plants or on hard substrates are also very frequent. In the uppermost strata of the Elphidium reginum Zone, a biofacies containing Cibicides, Articulina and Nodophthalmidium indicates near-shore settings and occurs together with Bolivina which prefers a deeper environment (Görög, 1992).

The total species diversity, the slight diversification towards the upper part of the Elphidium reginum Zone (mainly for the foraminifera) and the values of the $R$ index suggest an increase in the stability of the environmental factors (Fig. 4).

\section{4.b. Elphidium hauerinum Zone}

At the boundary between the Elphidium reginum and Elphidium hauerinum zones, a significant change is observed in the composition of the ostracod and foraminifer assemblages, without distinct lithological variations or depositional hiatus. The microfauna is less diversified in this zone than in the lower one. Kollmann (1958), Jiřiček (1974) and Zelenka (1990) reached a similar conclusion for the ostracod fauna of the Vienna Basin. Eight species vanished and only three taxa (Amnicythere sp., Aurila notata and Loxoconcha 


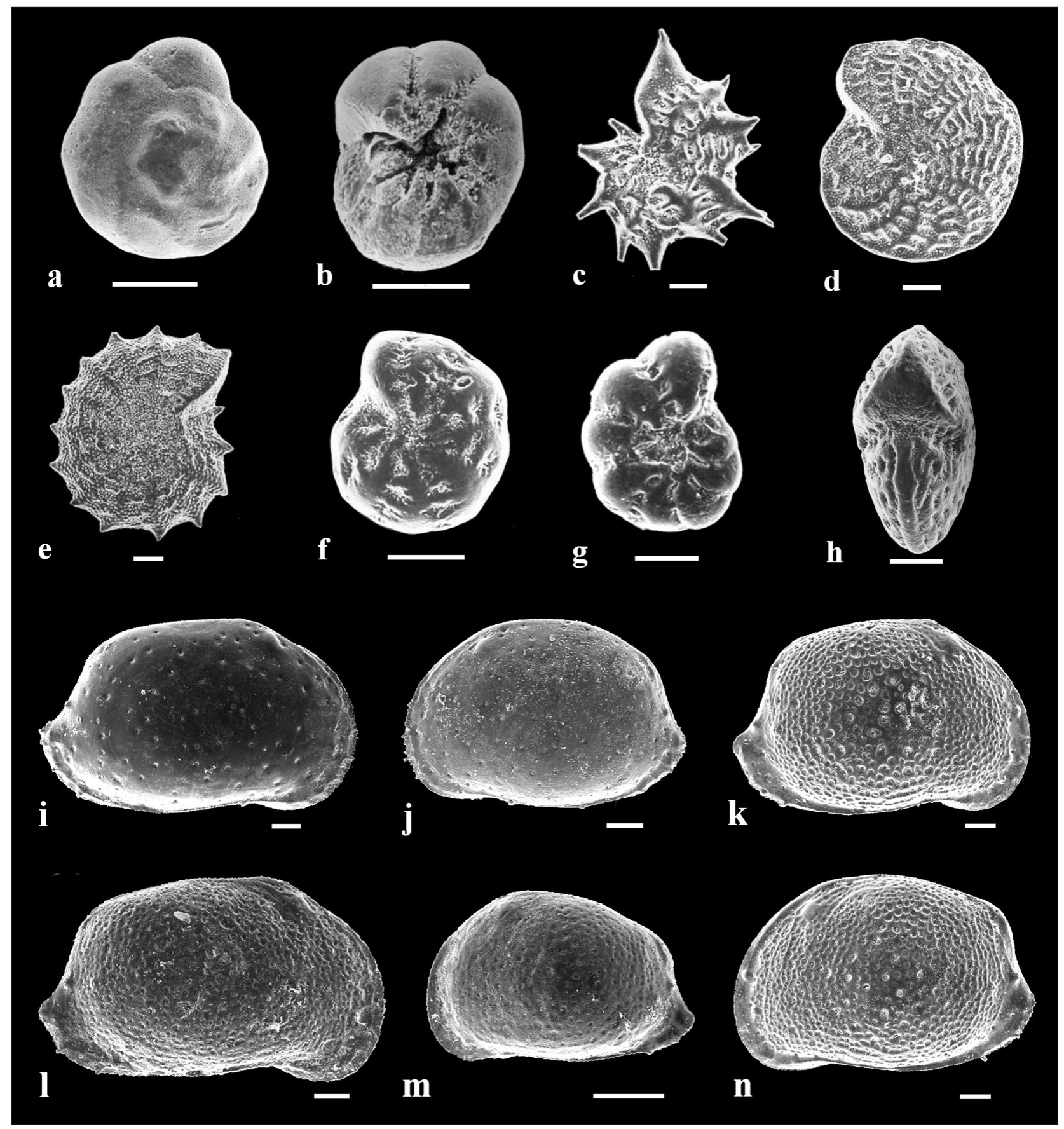

Figure 7. Foraminifer and ostracod species used for geochemical analyses. Scale bar $=100 \mu \mathrm{m}$ (a) Ammonia beccarii (Linné). Dorsal side. Perbál-5 borehole, depth 98-104 m. (b) Ammonia beccarii (Linné). Ventral side. Perbál-5 borehole, depth $98-104 \mathrm{~m}$. (c) Elphidium aculeatum (d'Orbigny). Side view of a juvenile specimen. Mány-17 borehole, depth 152.8-153 m. (d) Elphidium macellum (Fichtel \& Moll). Side view. Mány-22 borehole, depth 170-173 m. (e) Elphidium aculeatum (d'Orbigny). Side view of an adult specimen. Mány-17 borehole, depth 152.8-153 m. (f, g) Elphidium hauerinum (d'Orbigny). Side view. Perbál-5 borehole, depth 128.8-134.4 m. (h) Elphidium macellum (Fichtel \& Moll). Apertural view. Mány-22 borehole, depth 170-173 m. (i) Aurila mehesi (Zalányi). RV. Mány-17 borehole, depth 168.7-171.2 m. (j) Aurila mehesi (Zalányi). LV. Mány-17 borehole, depth 168.7-171.2 m. (k) Aurila notata (Reuss). RVo. Mány-22 borehole, depth 45-52.5 m. (1) Aurila notata (Reuss). RVơ . Mány-22 borehole, depth 70-72 m. (m) Aurila notata (Reuss). LV, juvenile specimen. Mány-22 borehole, depth 70-72 m. (n) Aurila notata (Reuss). LVo. Mány-22 borehole, depth 45-52.5 m.

porosa) appeared in this zone. In the lowermost beds of the Elphidium hauerinum Zone, the so-called small-sized ostracods (Amnicythere, Euxinocythere, Callistocythere, Loxoconcha, Xestoleberis) became conspicuous elements. Above all, very thin-shelled and unusually small specimens of Xestoleberis are very frequent in these layers. The thin, smooth valves and the small size suggest poorly oxygenated and/or cold water (Hartmann, 1975). The latter condition is unlikely because the presence of Callistocythere indicates warm waters (Morkhoven, 1962). Above these beds, the large and more ornamented Aurila 
notata and Hemicytheria omphalodes are dominant. Their distribution depends on the substrate type: Aurila prefers mixed sediments, while Hemicytheria has a preference for sandy bottoms (Cernajsek, 1972), a pattern agreeing with our observations.

In the lowermost beds of the Elphidium hauerinum Zone, infaunal foraminifera (Bolivina, Bulimina, Buliminella, Caucasina, Cassidulina, non-keeled elphidiids) become dominant beside the scanty miliolids and the elongated, uncoiled Articulina-type assemblage. These infaunal groups indicate colder (more temperate) and deeper waters and are generally associated with fine-grained, organic-rich sediments (Murray, 1991; Görög, 1992). In the upper part of the zone, the fauna is characterized by the dominance of euryhaline infaunal genera such as Ammonia and Nonion. The presence of Ammonia in great abundance indicates shallow (less than $50 \mathrm{~m}$ ), warm-temperate waters.

The decreasing trend of the total species diversity of ostracods and foraminifera (mainly in the Mány22 borehole) indicates a greater instability of the environment towards the end of this zone. The values of the Jaccard's index are lower in the Elphidium hauerinum Zone than in the Elphidium reginum Zone, suggesting a higher instability of the fauna in the middle zone (Fig. 4).

\section{4.c. Spirolina austriaca Zone}

At the boundary between the underlying Elphidium hauerinum Zone and the Spirolina austriaca Zone, a pronounced diversity increase is observed in the ostracod and foraminifer assemblages. Seven ostracod species appear (Cnestocythere aff. truncata, Euxinocythere naca, E. praebosqueti, Cyamocytheridea derii, C. leptostigma leptostigma, Miocyprideis janoscheki and Loxoconcha kochi). In this upper zone Aurila notata is generally most frequent, except in a few layers where Cyamocytheridea leptostigma leptostigma is prevalent. A few Badenian species (e.g. Cyamocytheridea derii, C. leptostigma leptostigma, Miocyprideis janoscheki) occur in this zone, while they are absent in the lower Sarmatian layers as well as in the foraminiferal fauna (e.g. Spirolina austriaca, Schlumbergerina fabularoides) (Görög, 1992; Tóth, 2008). The appearance of Cnestocythere in these beds is noteworthy because this genus is known exclusively from normal marine environments (Morkhoven, 1963). The ostracod fauna indicates shallow (epineritic, infrato circalittoral) settings with almost normal marine conditions.

The foraminiferal assemblages show a similar overall trend. The fauna is more diverse, and some species appear, mainly among the Hauerinidae which normally live in greater numbers in shallow and warm to warm-temperate waters of the infralittoral zone at depths between 30 and $50 \mathrm{~m}$. The mass occurrences of a finely agglutinated species, Schlumbergerina fabularoides, indicate shallow waters with a sandy substrate at depths of about 10-30 m (although this species may have been transported a short distance downslope into deeper parts of the sedimentary basin). Moreover, the great abundance of Triloculina and Milionella and the presence of irregularly coiled specimens of Hauerinidae suggest the development at times of hypersaline conditions (Murray, 1991). Spirolina austriaca, a very frequent species in this zone, probably favours normal to elevated salinities, because the present-day Spirolina pertusus is very abundant in hypersaline (40-70\%) areas (Haig, 1988). This is also supported by the presence of evaporites in the same stratigraphic level a few kilometres south of the studied area (Jámbor, 1974).

Significant diversifications and renewals of the ostracod and foraminifer faunas are indicated by higher values of the total species diversity in the Spirolina austriaca Zone than in the underlying one, but the low Jaccard's indices (except for the ostracods in Mány17) suggest a high faunal instability that is probably caused by variations in salinity (close to normal marine to hypersaline) and in temperature conditions of these shallow waters (Fig. 4).

\section{Geochemical results (see online Appendix}

Tables A3, A4)

$\mathrm{Mg}$ over Ca ratios have been analysed along with stable isotope compositions $\left(\delta^{13} \mathrm{C}\right.$ and $\left.\delta^{18} \mathrm{O}\right)$ on the same material for gastropods $(n=22)$. Data obtained from Mány-17 and Mány-22 boreholes are compiled together in Figure 8. Stable isotope ratios have been determined for all foraminifera (Ammonia, $\mathrm{n}=13$; Elphidium, $\mathrm{n}=46)$ and for all ostracod species $(\mathrm{n}=27)$, but $\mathrm{Mg} / \mathrm{Ca}$ ratios were not measured on these samples due to an insufficient amount of material.

The $\mathrm{Mg} / \mathrm{Ca}$ ratios of the gastropod skeletons belonging to the Elphidium reginum and Elphidium hauerinum zones exhibit a narrower range of values (between 0.14 and $0.34 \mathrm{mmol} \mathrm{mol}^{-1}$ ), in contrast to the great fluctuations of $\mathrm{Mg} / \mathrm{Ca}$ ratio in the upper zone (from 0.13 to $0.91 \mathrm{mmol} \mathrm{mol}^{-1}$ ). $\delta^{18} \mathrm{O}$ values range from -2.1 to $1.3 \%$. $\mathrm{Mg} / \mathrm{Ca}$ ratios and $\delta^{18} \mathrm{O}$ values are not correlated $\left(\mathrm{r}^{2}=0.2\right)$ (Fig. 8).

Both carbon and oxygen isotope compositions of foraminifera (Ammonia and Elphidium) and ostracods lie in comparable ranges for the Mány-17 and Mány22 boreholes. No significant differences are observed between $\delta^{18} \mathrm{O}$ values of foraminifera and ostracods, all ranging from $-3.5 \%$ to $-0.5 \%$ (Fig. 9). A progressive increase in $\delta^{18} \mathrm{O}$ values from about $-3 \%$ up to $-0.5 \%$ towards the end of the Elphidium reginum Zone is best illustrated by the foraminifera in the Mány-22 borehole, from which numerous samples were analysed with a high stratigraphic resolution. Foraminifera from the same borehole combined with ostracods from borehole Mány-17 show that the oxygen isotope compositions decrease in the Elphidium hauerinum zone and at the beginning of the Spirolina austriaca zone (Fig. 10). 


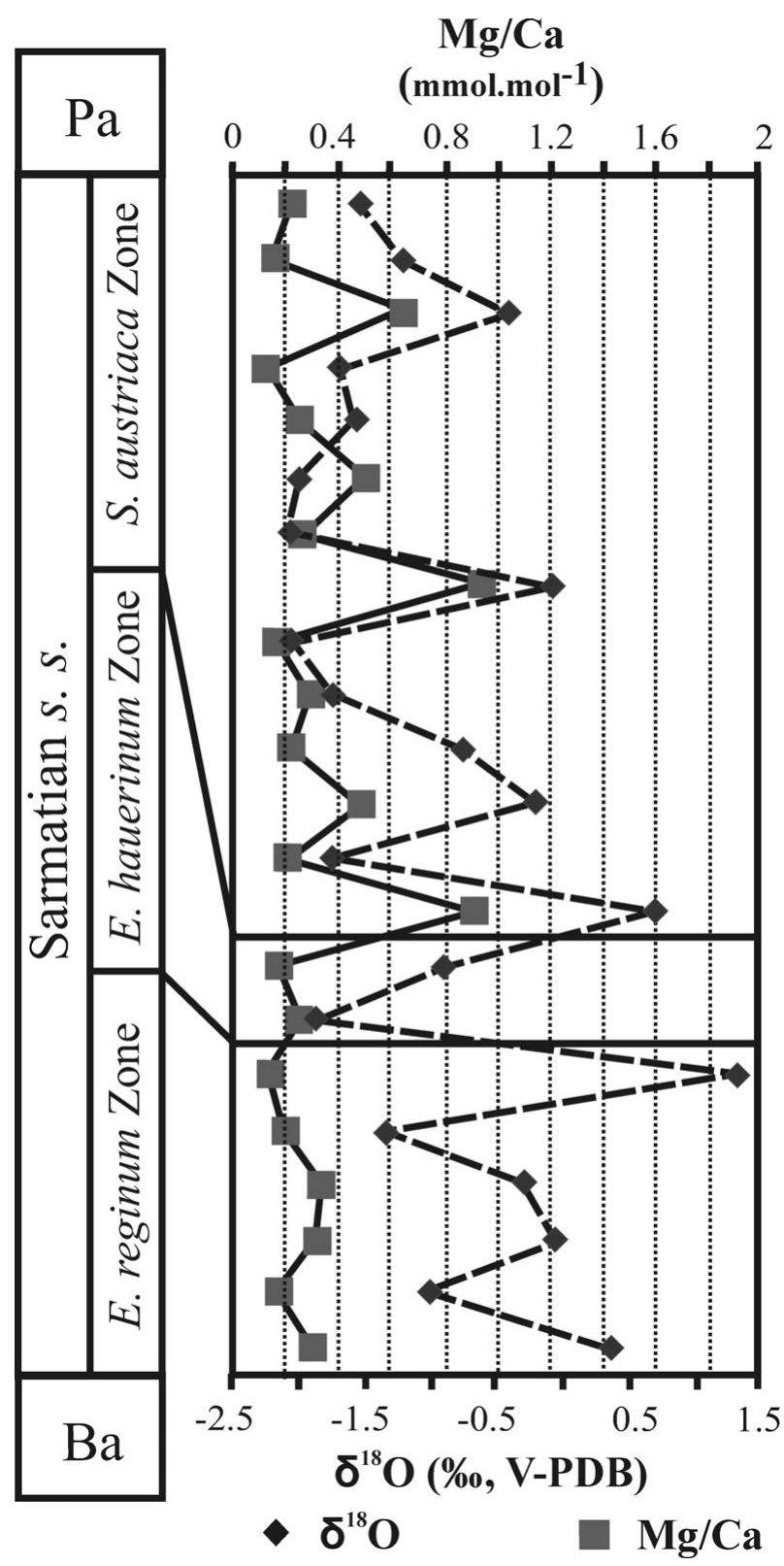

Figure 8. Comparison of $\mathrm{Mg} / \mathrm{Ca}$ and $\delta^{18} \mathrm{O}$ data of gastropods from the Zsámbék Basin. $\mathrm{Ba}$ - Badenian; $\mathrm{Pa}$ - Pannonian.

Ostracods in both boreholes as well as foraminifera from the Mány-22 borehole clearly show an abrupt decrease of $\delta^{13} \mathrm{C}$ values at the Elphidum reginum/Elphidium hauerinum Zone boundary, despite large differences in absolute values, ostracods having much lower $\delta^{13} \mathrm{C}$ values than foraminifera and gastropods (Figs 9, 10). In the upper zone, the carbonate skeletons of fossils are characterized by higher $\delta^{13} \mathrm{C}$ values than in the middle zone, but they have lower carbon isotope compositions than in the lower zone (Fig. 10).

Oxygen isotope compositions range from $17.7 \%$ to $19.8 \%$ for four samples of Sarmatian rodent teeth from Felsőtárkány and Tăşad (Table 1 ). The $\delta^{18} \mathrm{O}$ value from the Lower Sarmatian teeth is $17.7 \%$, while the average of the oxygen isotope compositions from the Upper Sarmatian teeth is $18.4 \%$.

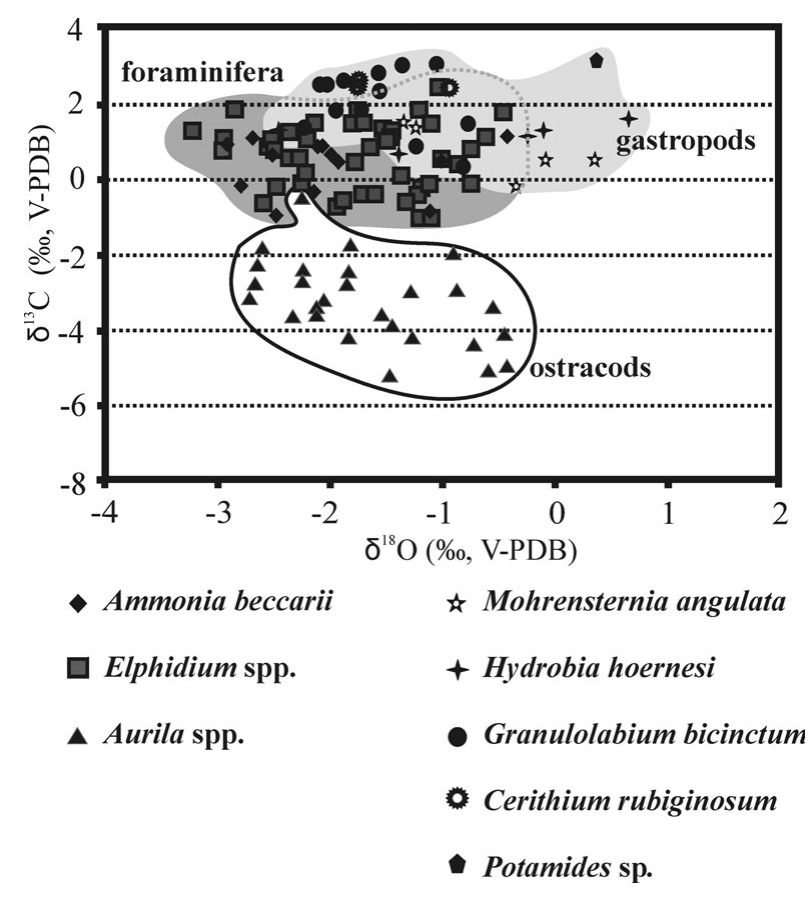

Figure 9. Oxygen isotope and carbon isotope variations of foraminifera (Elphidium spp., Ammonia beccarii), ostracods (Aurila spp.) and gastropods (Mohrensternia angulata, Hydrobia hoernesi, Granulolabium bicinctum, Cerithium rubiginosum, Potamides sp.) from different boreholes of the Zsámbék Basin.

\section{Discussion}

6.a. Estimation of water temperature and salinity based on phosphate and carbonate geochemical data

The oxygen isotope composition of freshwater inputs to the Central Paratethys is assumed to be directly derived from local meteoric waters whose $\delta^{18} \mathrm{O}$ value is estimated from the rodent teeth compositions (Table 1). Using the fractionation equation established by Navarro et al. (2004) for modern rodents, a $\delta^{18} \mathrm{O}$ value of $-5.7 \%$ for the Early Sarmatian and a $\delta^{18} \mathrm{O}$ range of -5.5 to $-2.2 \%$ for the Late Sarmatian are computed for the freshwater end-members (Table 1). The Early Sarmatian data coincide well with the $\delta^{18} \mathrm{O}$ value of meteoric water estimated from the $c .13 .5 \mathrm{Ma}$ large mammal teeth of the Steinheim Basin (Tütken et al. 2006). Since correlations have also been established between the weighted oxygen isotope composition of precipitation and mean annual air temperature (MAT) at middle to high latitudes (von Grafenstein et al. 1996), the combination of both relations leads to an estimated MAT between 15 and $21^{\circ} \mathrm{C}$ (Table 1). We emphasize that this method was applied to rodent teeth assuming that the present-day relationship between $\delta^{18} \mathrm{O}$ in precipitation and air temperature is valid for the Sarmatian. This air temperature estimate is similar to other estimates based on palaeoflora from the same outcrops (Erdei et al. 2007) and more generally from the Pannonian Basin (Jiménez-Moreno et al. 2005).

The next step is to consider that this mean annual air temperature could parallel the mean temperature of surface waters in the Central Paratethys. According 

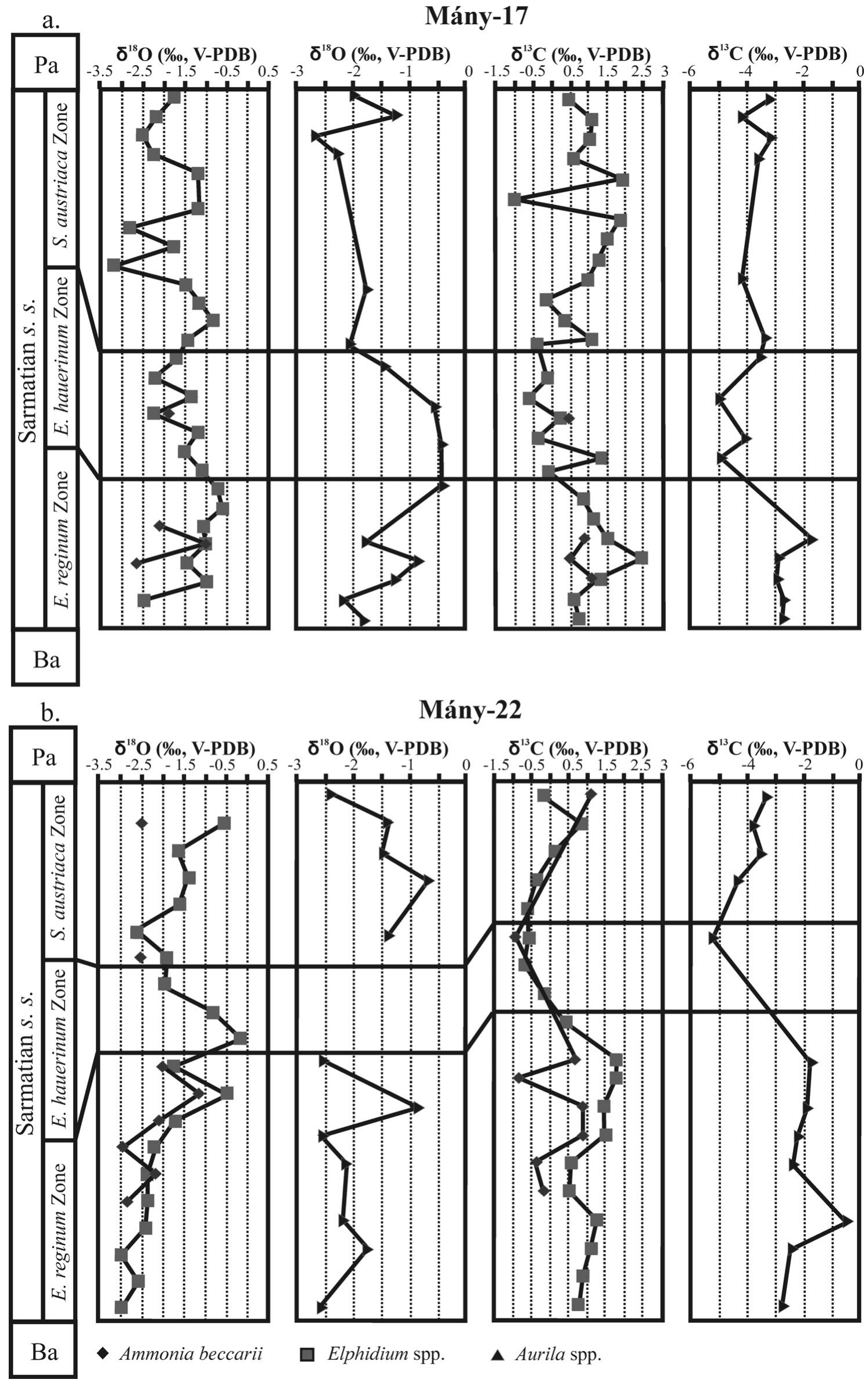

Figure 10. Oxygen and carbon isotope compositions of foraminifera and ostracods from the Zsámbék Basin. $\mathrm{Ba}-\mathrm{Badenian}$; Pa Pannonian. 
Table 2. Oxygen isotope compositions of aquatic gastropods $\left(\delta^{18} \mathrm{O}_{\mathrm{a}}\right)$ and estimates of seawater composition and salinity

\begin{tabular}{|c|c|c|c|c|}
\hline Biostratigraphic position & $\begin{array}{c}\delta^{18} \mathrm{O}_{\mathrm{a}} \\
(\% \mathrm{o})\end{array}$ & $T_{w}\left({ }^{\circ} \mathrm{C}\right)$ & $\delta^{18} \mathrm{O}_{\mathrm{w}}{ }^{*}$ & $S^{* *}\left(\mathrm{~g} .1^{-1}\right)$ \\
\hline \multicolumn{5}{|l|}{ Elphidium reginum Zone } \\
\hline Min. value & -1.4 & 15 & -2.6 & 20 \\
\hline Max. value & 0.4 & 15 & -0.9 & 32 \\
\hline Average & -0.7 & 15 & -1.9 & 25 \\
\hline \multicolumn{5}{|l|}{ Elphidium hauerinum Zone } \\
\hline Min. value & -1.9 & 15 & -3.1 & 17 \\
\hline Max. value & -0.9 & 15 & -2.1 & 23 \\
\hline Average & -1.4 & 15 & -2.6 & 20 \\
\hline \multicolumn{5}{|c|}{ Spirolina austriaca Zone $\left(T_{1}=15^{\circ} \mathrm{C}\right)$} \\
\hline Min. value & -2.2 & 15 & -3.4 & 15 \\
\hline Max. value & 0.7 & 15 & -0.5 & 34 \\
\hline Average & -1.3 & 15 & -2.5 & 21 \\
\hline \multicolumn{5}{|c|}{ Spirolina austriaca Zone $\left(T_{2}=21^{\circ} \mathrm{C}\right)$} \\
\hline Min. value & -2.2 & 21 & -2.1 & 24 \\
\hline Max. value & 0.7 & 21 & 0.9 & 43 \\
\hline Average & -1.3 & 21 & -1.1 & 30 \\
\hline
\end{tabular}

${ }^{*} \delta{ }^{18} \mathrm{O}$ values of seawater was computed using the aragonite-water fractionation equation determined by Grossman \& Ku (1986):

$$
\mathrm{T}_{\mathrm{w}}=21.8-4.69^{*}\left(\delta^{18} \mathrm{O}_{\mathrm{a}}-\delta^{18} \mathrm{O}_{\mathrm{w}}\right)
$$

** Salinity of seawater was estimated using a mass balance equation:

$$
\mathrm{S}=34^{*}\left(1-\left(\delta^{18} \mathrm{O}_{\mathrm{w}}+0.5\right) /(-5.66+0.5)\right)
$$

to this assumption, $\delta^{18} \mathrm{O}$ values of seawater can be computed by using the aragonite-water fractionation equation determined by Grossman \& $\mathrm{Ku}$ (1986) from the temperature and the isotopic compositions of shallow-water gastropod shells that are known to precipitate their carbonate skeleton in oxygen isotope equilibrium with seawater (Grossman \& $\mathrm{Ku}, 1986$; Lécuyer, Reynard \& Martineau, 2004) (Table 2). Assuming that the shallow Sarmatian Sea was homogeneous in temperature we obtain the $\delta^{18} \mathrm{O}$ values of the seawater (Table 2).

The oxygen isotope composition of the marine end-member can be considered as close to $-0.5 \%$, according to the $\delta^{18} \mathrm{O}$ values of shark teeth from Badenian beds of the Pannonian and Vienna basins (Kocsis et al. 2009). The corresponding salinity is about $34 \%$ for a period preceding the onset of the major stage of Antarctic ice growth (Zachos et al. 2001). These $\delta^{18} \mathrm{O}$ and salinity values for both water end-members (freshwater with $\delta^{18} \mathrm{O}$ values of $-5.6 \%$ ) are used to reconstruct the changes in salinities that occurred in the Sarmatian Central Paratethys.

In the Elphidium reginum and Elphidium hauerinum zones, the near constant $\mathrm{Mg} / \mathrm{Ca}$ ratios of gastropods suggest a stable water temperature (Fig. 8). The $\delta^{18} \mathrm{O}$ values of gastropods, ranging from -1.4 to $0.4 \%$, correspond to salinities from 20 to $32 \%$, the maximum values being recorded at the end of the lower zone. The middle zone, with similar $\mathrm{Mg} / \mathrm{Ca}$ ratios, is characterized by $\delta^{18} \mathrm{O}$ values of gastropods ranging from -1.9 to $-0.9 \%$, without any marked temporal trend. These $\delta^{18} \mathrm{O}$ values correspond to salinities between 17 and $23 \%$ (Table 2). The Spirolina austriaca Zone is characterized by various $\mathrm{Mg} / \mathrm{Ca}$ ratios reflecting fluctuations in water temperature (Fig. 8). They correlate well with the large range in temperatures $\left(15-21{ }^{\circ} \mathrm{C}\right)$ calculated from the phosphate data. The $\delta^{18} \mathrm{O}$ values of the gastropods, fluctuating over time, range from -2.2 to $0.7 \%$, and they were used to compute salinity values between 15 and $43 \%$ (Table 2).

\section{6.b. Integrated interpretation of the palaeontological and geochemical records}

\section{6.b.1. Elphidium reginum Zone}

The ostracod, foraminifer and mollusc faunas of the Lower Sarmatian beds are characterized by their low diversity, great abundance of euryhaline taxa and almost complete lack of stenohaline forms, contrary to the highly diversified, normal marine Badenian faunas. The microfauna suggests shallow, warm-temperate, well-ventilated seawater (littoral zone, maximum $80 \mathrm{~m}$ deep) with rich algae and/or seagrass vegetation on the bottom. The change in foraminiferal fauna (appearance of large elphidiids above the Hauerinarich layers) indicates increasing water depths in this zone. At the end of the Elphidium reginum Zone the appearance of infaunal Bolivina also indicates deeper conditions. The presence and abundance of partially redeposited foraminifera of the Cibicides and Articulina-type assemblages suggest the expansion of the area covered by shallow waters. The quantitative analyses of the microfauna (total species diversity and $R$ ) indicate an increase in the stability of this previously unstable environment towards the end of this zone (Fig. 4). This phenomenon and the positive shifts in the $\delta^{18} \mathrm{O}$ and $\delta^{13} \mathrm{C}$ profiles are presumably indicative of a seawater incursion into the semi-open basin system of the Central Paratethys at the end of the Elphidium reginum Zone (Fig. 10). The $\mathrm{Mg} / \mathrm{Ca}$ profile of the gastropod shells suggests more or less stable and constant bottom-water temperature conditions during the Early Sarmatian in the Zsámbék Basin (Fig. 8). As there is no correlation between the $\delta^{18} \mathrm{O}$ and $\mathrm{Mg} / \mathrm{Ca}$ profiles of gastropod shells, we can exclude the influence of temperature in the oxygen isotope trends. The $\delta^{18} \mathrm{O}$ profiles are thus likely controlled by changes in salinity.

In the Elphidium reginum Zone a transgressive event can be observed as part of a 3rd order transgressive systems tract (TST) corresponding roughly to the TB 2.6 global cycle of Haq, Hardenbol \& Vail (1988). Based on sequence stratigraphy, palaeontological and sedimentological analyses of the Sarmatian deposits, evidence of this phenomenon was also shown by Harzhauser \& Piller (2004b) and Kováć et al. (2004) in the Vienna Basin, by Schreilechner \& Sachsenhofer (2007) in the Styrian Basin, by Krézsek \& Filipescu (2005) and Filipescu, Silye \& Krézsek (2005) in the Transylvanian Basin and by Vrsaljko et al. (2006) in Croatia. This transgressive pulse culminated in a seawater incursion at the end of this zone. This 
hypothesis seems to be supported by the predominance of planktonic marine diatoms and silicoflagellates in the Lower Sarmatian diatomite intercalations of the Zsámbék Basin (Hajós, 1986).

From the geochemical analyses of the rodent teeth and the gastropod shells, temperatures of about $15^{\circ} \mathrm{C}$ and salinities of 20-32\% were estimated for the Early Sarmatian seawater (Tables 1, 2).

\section{6.b.2. Elphidium hauerinum Zone}

At the boundary between the Elphidium reginum and Elphidium hauerinum zones, the diversity of the microfauna decreased greatly. In the lowermost beds of the Elphidium hauerinum Zone, the smallsized, thin and smooth-shelled ostracods and the infaunal foraminifera (Bolivina, Bulimina, Buliminella, Caucasina, Cassidulina and non-keeled elphidiids) indicate colder (temperate) and deeper, less oxygenated waters than in the lower zone. The carbon isotope profiles of foraminifera, ostracod and gastropod shells also suggest less oxygenated, organic-rich sediments, because the negative shift in the $\delta^{13} \mathrm{C}$ values is caused by the oxidative processes in the surrounding organic-rich sediments (Fig. 10). The decomposition of organic matter releases ${ }^{12} \mathrm{C}$-enriched $\mathrm{CO}_{2}$ to the bottom water in which the biogenic carbonate precipitated. The presence of such organic-rich sediments can be explained by the maximum input of organic matter correlated with a relative sea-level rise. A similar event was demonstrated by Harzhauser \& Piller (2004b) and Kovać et al. (2004) in the Vienna Basin. They consider this event as corresponding to a 3rd order HST (highstand systems tract).

Above these beds, the upper part of the Elphidium hauerinum Zone is characterized by large and more ornamented ostracods. Among the foraminifera the euryhaline genera Ammonia and Nonion become dominant. The presence of Ammonia in great abundance indicates shallow (less than $50 \mathrm{~m}$ deep), warmtemperate waters. The microfauna of the upper part of the Elphidium hauerinum Zone indicates a relativesea-level fall which is confirmed by the results of Harzhauser \& Piller (2004b) and Kovać et al. (2004), who demonstrated evidence of a LST (lowstand systems tract).

The decreasing trend of the total species diversity, and the changes in Jaccard's indices $(R)$ of the ostracods and foraminifera suggest a higher instability in this zone than in the lower one (Fig. 4). These characters can be explained by the relative sea-level changes because the $\mathrm{Mg} / \mathrm{Ca}$ profile indicates nearly constant bottomwater temperatures with the same values as in the lower zone (Fig. 8). The estimated salinity for this zone is $17-$ $23 \%$ (Table 2).

\section{6.b.3. Spirolina austriaca Zone}

In this zone the microfauna is more diversified than in the previous one. Several Badenian foraminifer and ostracod species which are missing from the lower Sarmatian beds occur here. A similar phenomenon was documented by changes in gastropod faunas from the Vienna Basin (Harzhauser \& Kowalke, 2002). Based on the quantitative analyses of the microfauna, significant diversification and renewal events of the ostracod and foraminifer faunas are indicated by higher values of the total species diversity in the Spirolina austriaca Zone than in the Elphidium hauerinum Zone (Fig. 4). These results correlate well with those of Steininger \& Wessely (2000), who demonstrated that a narrow marine connection existed between the Eastern Mediterranean and the Eastern Paratethys and that a seaway connected the Eastern and the Central Paratethys at the end of the Sarmatian. The existence of these marine gateways is also supported by the results of Iljina (1998) from the Eastern Paratethys.

The ecological interpretation of the ostracod and foraminifer faunas, together with the lithological and sedimentological features, indicate warm, wellventilated shallow lagoon and marsh environments, which occasionally became hypersaline. The $\delta^{18} \mathrm{O}$ values and $\mathrm{Mg} / \mathrm{Ca}$ ratios are very scattered, indicating fluctuations in bottom-water temperatures and salinity (Figs 8, 10). The estimated temperatures are $15-21^{\circ} \mathrm{C}$ and the salinity $15-43 \%$ (Table 2 ).

However, the Sarmatian fauna from the studied boreholes in the Zsámbék Basin clearly indicates episodic marine incursions associated with a sea-level rise during the deposition of the upper zone. The occurrence of shallow lagoon and intertidal marsh facies in the basin can be explained by re-deposition from the margins. Similar events were described by Kováć et al. (2004) from the Vienna Basin. Due to unstable shallow-water environmental conditions, there is no evidence for seawater incursions in stable isotope data, and for the transgressive event in changes of the lithology (e.g. the presence of the oolithic limestones).

\section{Conclusions}

The studied Sarmatian successions have been subdivided into three parts on the basis of earlier investigations of the foraminiferal fauna (Görög, 1992) and the current study of the ostracod assemblages. These findings are compared with geochemical data to reconstruct the depositional history of the Zsámbék Basin and to explain the main changes occurring at the zone boundaries.

The lowermost Sarmatian beds of the Elphidium reginum Zone are characterized by low diversity faunal assemblages and the almost complete absence of stenohaline forms. Evidence for a transgressive event is then shown by the foraminiferal and isotopic data, with relatively stable bottom-water temperatures and periodic siliceous phytoplankton blooms. Similar trends were documented from other Paratethyan basins (Rögl, Steininger \& Müller, 1978; Steininger \& Wessely, 2000; Harzhauser \& Piller, 2004b; Kováč et al. 2004; Krézsek \& Filipescu, 2005; Schütz et al. 2007). 
The lower part of the middle Sarmatian Elphidium hauerinum Zone displays a decrease in the taxonomic diversity of the foraminifera and ostracods. The microfaunal composition and the carbon isotope profiles indicate a sea-level highstand with relatively poorly oxygenated bottom waters. This environment changes later into well-ventilated lowstand conditions in the upper part of this zone. This regressive event is also supported by the results of Harzhauser \& Piller (2004b) and Kovać et al. (2004).

At the boundary between the Elphidium hauerinum and Spirolina austriaca zones, the microfaunal diversity is again increased by the re-appearance of Badenian species which had vanished completely at the base of the Sarmatian. This is explained by a restored connection between the Paratethys and the Mediterranean. The renewal of the microfauna and the salinity estimated using geochemical data indicate close to normal marine conditions, with local development of slightly hypersaline environments. These phenomena can be explained by episodic marine incursions and evaporative processes. The Spirolina austriaca Zone is also characterized by fluctuating bottom-water temperatures.

Acknowledgements. We are grateful to János Hír for providing the rodent teeth and to Jean-Jacques Cornée for helpful discussions during the preparation of this paper. The authors thank François Fourel and François Martineau (both at University of Lyon, UMR 5125) for their technical assistance during the oxygen and carbon isotope analysis of carbonate and phosphate samples. Trace element analyses were carried out at the Ecole Normale Superieure of Lyon with the help of Philippe Telouk and Chantal Douchet. The Hantken Foundation is acknowledged for support. This is contribution UMR 5125-09.XXX, MTA-MTM Paleo contribution No. 91.

\section{References}

ANDRUSOV, N. 1902. Die südrussischen Neogenablagerungen. 3-ter Theil. Verhandlungen der RussischKaiserlichen Mineralogischen Gesellschaft zu St. Petersburg 39(2), 337-495.

BoDA, J. 1959. A magyarországi szarmata emelet és gerinctelen faunája (Das Sarmat in Ungarn und seine Invertebraten-Fauna). Annales Instituti Geologici Publici Hungarici 47(3), 567-862 (in Hungarian and German).

BODA, J. 1974. A magyarországi szarmata emelet rétegtana (Stratigraphie des Sarmats in Ungarn). Földtani Közlöny 104(3), 249-60 (in Hungarian, German abstract).

CernajseK, T. 1972. Zur Palökologie der Ostrakodenfaunen am Westrand des Wiener Beckens. Verhandlungen der Geologischen Bundesanstalt 1972/2, 237-46.

CORnÉE, J.-J., MOISSETTE, P., SAINT MARTIN, J.-P., KÁZMÉR, M., Tóth, E., GöröG, Á., Dulai, A. \& Müller, P. 2009. Marine carbonate systems in the Sarmatian of the Central Paratethys: the Zsámbék Basin of Hungary. Sedimentology, doi:10.1111/j.1365-3091.2009.01055.x, in press.

Crowson, R. A., Showers, W. J., Wright, E. K. \& HoERING, T. C. 1991. A method for preparation of phosphate samples for oxygen isotope analysis. Analytical Chemistry 63, 2397-400.

DODD, J. R. \& CRISP, E. L. 1982. Non-linear variation with salinity of $\mathrm{Sr} / \mathrm{Ca}$ and $\mathrm{Mg} / \mathrm{Ca}$ ratios in water and aragonitic bivalve shells and implications for palaeosalinity studies. Palaeogeography, Palaeoclimatology, Palaeoecology 38, 45-56.

EIJDEN, A. J. M. VAN \& GANSSEN, G. M. 1995. An Oligocene multi-species foraminiferal oxygen and carbon isotope record from ODP Hole 758A (Indian Ocean): paleoceanographic and paleo-ecologic implications. Marine Micropaleontology 25, 47-65.

Epstein, S., Buchsbaum, R., Lowenstam, H. A. \& UREY, H. C. 1953. Revised carbonate-water isotopic temperature scale. Bulletin of the Geological Society of America 64, 1315-26.

ERdeI, B., HABLY, L., KÁZMÉR, M., UTESCHER, T. \& BRUCH, A. A. 2007. Neogene flora and vegetation development in the Pannonian domain in relation to palaeoclimate and palaeogeography. Palaeogeography, Palaeoclimatology, Palaeoecology 253, 131-56.

FILIPESCU, S., POPA, M. \& WANEK, F. 1999. The significance of some Sarmatian faunas from the southwestern part of the Padurea Craiului Mountains (Romania). Acta Palaeontologica Romaniae 2, 163-9.

FILIPESCU, S., SilYE, L. \& KRÉZSEK, Cs. 2005. Sarmatian micropaleontological assemblages and sedimentary paleoenvironments in the southern Transylvanian Basin. Acta Palaeontologica Romaniae 5, 173-9.

FORDINÁL, K., ZÁGORSEK, K. \& ZLINSKÁ, A. 2006. Early Sarmatian biota in the northern part of the Danube Basin (Slovakia). Geologica Carpathica 57, 123-30.

GöRÖG, Á. 1992. Sarmatian foraminifera of the Zsámbék Basin, Hungary. Annales Universitatis Scientiarum Budapestinensis, sectio Geologica 29, 31-153.

GrafEnsteIn, U. VON, ERLENKEUSER, H., MÜller, J., TRIMBORN, P. \& AlEFS, J. 1996. A 200 year middleEuropean air temperature record preserved in lake sediments: An extension of the $\delta^{18} \mathrm{O}_{\mathrm{p}}$-air temperature relation into the past. Geochimica et Cosmochimica Acta 60, 4025-36.

GRILL, R. 1941. Stratigraphische Untersuchungen mit Hilfe von Mikrofaunen im Wiener Becken und den benachbarten Molasse-Anteilen. Öl Kohle 37, 595-602.

Grossmann, E. L. \& KU, T. L. 1986. Stable oxygen and carbon isotope fractionation in biogenic aragonite: temperature effect. Chemical Geology, Isotope Geoscience Section 59, 59-74.

HAIG, D. W. 1988. Miliolids foraminifera from inner neritic sand and mud facies of the Papua lagoon, New Guinea. Journal of Foraminiferal Research 18, 203-36.

HAJós, M. 1986. A magyarországi miocén diatómás képződmények rétegtana (Stratigraphy of Hungary's Miocene diatomaceous earth deposits). Geologica Hungarica 49, 1-339 (in Hungarian and English).

HÁMOR, G. 1997. Kozárdi Formáció (Kozárd Formation). In Magyarország Litosztratigráfiai Alapegységei (Basic Lithostratigraphic units of Hungary) (ed. G. Császár), p. 76. Budapest: Geological Institute of Hungary (in Hungarian and English).

HÁMOR, G. \& IVANCSICS, J. 1997. Tinnyei Formáció (Tinnye Formation). In Magyarország Litosztratigráfiai Alapegységei (Basic Lithostratigraphic units of Hungary) (ed. G. Császár), p. 76. Budapest: Geological Institute of Hungary (in Hungarian and English).

HaQ, B. U., HaRdenbol, J. \& VAIL, P. R. 1988. Mesozoic and Cenozoic chronostratigraphy and cycles of sea level changes. In Sea-level changes - an integrated approach 
(eds C. K. Wilgus, B. S. Hastings, C. G. Kendall, H.W. Posamentier, C. A. Ross \& J. C. van Wagoner), pp. 71-108. Society of Economic Paleontologists and Mineralogists, Special Publications no. 42.

HARTMANN, G. 1975. Ostracoda. In Dr. H. G. Bronns Klassen und Ordnungen des Tierreichs. 5. Arthropoda. 1. Crustacea (ed. H. E. Gruner), 2, 4, 4, pp. 572-616. Jena: VEB Gustav Fischer Verlag.

HARZHAUSER, M. \& KowalKe, T. 2002. Sarmatian (Late Middle Miocene) gastropod assemblages of the Central Paratethys. Facies 46, 57-82.

HARZHAUSER, M. \& PILleR, W. E. 2004a. Integrated stratigraphy of the Sarmatian (Upper Middle Miocene) in the western Central Paratethys. Stratigraphy 1, 65-86.

Harzhauser, M. \& PILler, W. E. 2004b. The Early Sarmatian - hidden seesaw changes. Courier Forschungsinstitut Senckenberg 246, 89-111.

Harzhauser, M., Piller, W. E. \& Latal, C. 2007. Geodynamic impact on the stable isotope signatures in a shallow epicontinental sea. Terra Nova 19, 324-30.

Hír, J. 2004. The Present Status of the Study on the Middle Miocene Rodent Faunas in the Carpathian Basin. Courier Forschungsinstitut Senckenberg 249, 45-52.

Hír, J., KóKAY, J., Venczel, M., GÁl, E. \& Kessler, E. 2001. Előzetes beszámoló a felsőtárkányi ,Güdör-kert” n. öslénytani lelöhelykomplex újravizsgálatáról. Folia Historico Naturalia Musei Matraensis 25, 41-64 (in Hungarian, English abstract).

ILJINA, L. B. 1998. Connections of Eastern Paratethyan paleobasins with Tethyan Seas in the Middle and Late Miocene. Romanian Journal of Stratigraphy 78, 5762.

JÁMBOR, Á. 1974. Üledékes kéntelep a Zsámbéki-medence szarmata sorozatában (Sedimentary sulfur deposit in the Sarmatian sequence of the Zsámbék Basin (Transdanubia, Hungary)). Magyar Állami Földtani Intézet Évi Jelentése, 301-3 (in Hungarian, English abstract).

JANZ, H. \& VENNEMANN, T. W. 2005. Isotopic composition $(\mathrm{O}, \mathrm{C}, \mathrm{Sr}$, and $\mathrm{Nd})$ and trace element ratios $(\mathrm{Sr} / \mathrm{Ca}$, $\mathrm{Mg} / \mathrm{Ca}$ ) of Miocene marine and brackish ostracods from North Alpine Foreland deposits (Germany and Austria) as indicators for palaeoclimate. Palaeogeography, $\mathrm{Pa}$ laeoclimatology, Palaeoecology 225, 216-47.

JiMÉNEZ-MORENO, G., RODRÍGUEZ, F.-J., PARDOIgúzQuiza, E., FAuQuetTe, S., Suc, J.-P. \& MÜller, P. 2005. High-resolution palynological analysis in late early-middle Miocene core from the Pannonian Basin, Hungary. Climatic changes, astronomical forcing and eustatic fluctuations in the Central Paratethys. Palaeogeography, Palaeoclimatology, Palaeoecology 216, 73-97.

JIŘIČEK, R. 1972. Problém hranice sarmat/panon ve Vídeňské, Podunajské a Východoslovenské pánvi (Das Problem der Grenze Sarmat/Pannon in dem Wiener Becken, dem Donaubecken und dem ostslowakischen Becken). Mineralia Slovaca 4(14), 39-81.

JIŘIČEK, R. 1974. Biostratigraphische Bedeutung der Ostracoden des Sarmats s. str. In Chronostratigraphie und Neostratotypen, Miozän der Zentralen Paratethys, 4 (ed. E. Brestenská), pp. 434-58. Bratislava: VEDA, Verlag der Slowakischen Akademie der Wissenschaften.

Kocsis, L., Vennemann, T. W., Hegner, E., Fontignie, D. \& TÜTKEN, T. 2009. Constraints on Miocene oceanography and climate in the Western and Central Paratethys: records of the O-, Sr-, and Nd-isotope composition of marine fish and mammal remains. $P a$ laeogeography, Palaeoclimatology, Palaeoecology 271, $117-29$.
Kollmann, K. 1958. Cytherideinae und Schulerideinae n. subfam. (Ostracoda) aus dem Neogen des östlichen Österreich. Mitteilungen der Geologischen Gesellschaft in Wien 51, 28-195.

Kováč, M., Baráth, I., Harzhauser, M., HLaVatÝ, I. \& HudÁČKOVÁ, N. 2004. Miocene depositional systems and sequence stratigraphy of the Vienna Basin. Courier Forschungsinstitut Senckenberg 246, 187-212.

KrÉZSEK, Cs. \& FILIPESCU, S. 2005. Middle to late Miocene sequence stratigraphy of the Transylvanian Basin (Romania). Tectonophysics 410, 437-63.

LANGER, M. R. 1995. Oxygen and carbon isotopic composition of recent larger and smaller foraminifera from the Madang Lagoon (Papua New Guinea). Marine Micropaleontology 26, 215-21.

Latal, C., Piller, W. E. \& Harzhauser, M. 2004. Palaeoenvironmental reconstructions by stable isotopes of Middle Miocene gastropods of the Central Paratethys. Palaeogeography, Palaeoclimatology, Palaeoecology 211, 157-69.

LÉCUYER, C., GRANDJEAN, P., O’NeIL, J. R., CAPPETTA, H. \& MARTINEAU, F. 1993. Thermal excursions in the ocean at the Cretaceous-Tertiary boundary (northern Morocco): the $\delta^{18} \mathrm{O}$ record of phosphatic fish debris. Palaeogeography, Palaeoclimatology, Palaeoecology 105, 23543.

LÉCUYer, C., GRANDJEAN, P., BARRAT, J.-A., NolvaK, J., EMIG, C., Paris, F. \& Robardet, M. 1998. $\delta^{18}$ O and REE contents of phosphatic brachiopods: a comparison between modern and lower Paleozoic populations. Geochimica et Cosmochimica Acta 62, 2429-36.

LÉCUYER, C., REYNARD, B. \& MARTINEAU, F. 2004. Stable isotope fractionation between mollusc shells and marine waters from Martinique Island. Chemical Geology 213, 293-305.

LUBINSKI, D. J., POlYAK, L. \& Forman, S. L. 2001. Freshwater and Atlantic water inflows to the deep northern Barents and Kara seas since ca $13{ }^{14} \mathrm{C}$ ka: foraminifera and stable isotopes. Quaternary Science Reviews 20, 1851-79.

LuCZKOWSKA, E. 1998. Marine Miocene deposits of the Paratethys in Poland. In Oligocene-Miocene foraminifera of the Central Paratethys (eds F. Rögl, C. Rupp \& J. Ctyroka), pp. 28-34. Abhandlungen der senckenbergischen naturforschenden Gesellschaft no. 549. Frankfurt am Main: Verlag Waldemar Kramer.

Magyar, I., Geary, D. H. \& Müller, P. 1999. Paleogeographic evolution of the Late Miocene Lake Pannon in Central Europe. Palaeogeography, Palaeoclimatology, Palaeoecology 147, 151-67.

MÁtyás, J., BuRns, S. J., MÜller, P. \& Magyar, I. 1996. What can stable isotopes say about salinity? An example from the late Miocene Pannonian Lake. Palaios 11, 319.

Morkhoven, F. P. C. M. 1962. Post-Palaeozoic Ostracoda, Vol. I. Amsterdam, London, New York: Elsevier Publishing Company, 204 pp.

Morkhoven, F. P. C. M. 1963. Post-Palaeozoic Ostracoda, Vol. II. Amsterdam, London, New York: Elsevier Publishing Company, 478 pp.

MURRAY, J. W. 1991. Ecology and Palaeoecology of Benthic Foraminifera. Essex: Longman Scientific \& Technical, $397 \mathrm{pp}$.

Navarro, N., LÉcuyer, C., Montuire, S., LANGlois, C. \& MARTINEAU, F. 2004. Oxygen isotope compositions of phosphate from arvicoline teeth and Quaternary climatic changes, Gigny, French Jura. Quaternary Research 62, 172-82. 
OERTLI, H. J. 1971. The aspect of ostracode faunas - A possible new tool in petroleum sedimentology. Bulletin du Centre de Recherche de Pau-SNPA 5, 13751.

O’NeIL, J. R., Roe, L. J., ReInHARD, E. \& BlaKe, R. E. 1994. A rapid and precise method of oxygen isotope analysis of biogenic phosphates. Israel Journal of Earth Sciences 43, 203-12.

PAPP, A. 1956. Fazies und Gliederung des Sarmats im Wiener Becken. Mitteilungen der Geologischen Gesellschaft in Wien 47, 35-98.

PAPP, A. 1974. Die Entwicklung des Sarmats in Österreich. In Chronostratigraphie und Neostratotypen, Miozän der Zentralen Paratethys, 4 (ed. E. Brestenská), pp. 75-7. Bratislava: VEDA, Verlag der Slowakischen Akademie der Wissenschaften.

Peros, M. C., Reinhardt, E. G., Schwarcz, H. P. \& DAVIS, A. M. 2007. High-resolution paleosalinity reconstruction from Laguna la Leche, north coastal Cuba, using $\mathrm{Sr}, \mathrm{O}$ and $\mathrm{C}$ isotopes. Palaeogeography, Palaeoclimatology, Palaeoecology 245, 53550.

Piller, W. E. \& Harzhauser, M. 2005. The myth of the brackish Sarmatian Sea. Terra Nova 17, 450-5.

PISERA, A. 1996. Miocene reefs of the Paratethys; a review. In Models for Carbonate Stratigraphy from Miocene Reef Complexes of Mediterranean Regions (eds E. K. Franseen, M. Esteban, W. C. Ward \& J. M. Rouchy), pp. 97-104. SEPM Concepts in Sedimentology and Paleontology no. 5.

POPESCU, G. 1995. Contribution to the knowledge of the Sarmatian foraminifera of Romania. Romanian Journal of Paleontology 76, 85-98.

Popov, S. V., RöGl, R., Rozanov, A. Y., SteInINGer, F. R., SHCHERBA, I. G. \& KovAC, M. 2004. LithologicalPaleogeographic maps of Paratethys. Courier Forschungsinstitut Senckenberg 250, 27-9.

Puri, H. S., Bonaduce, G. \& Gervasio, A. M. 1969. Distribution of Ostracoda in the Mediterranean. In The Taxonomy, Morphology and Ecology of Recent Ostracoda (ed. J. W. Neale), pp. 356-412. Edinburgh: Oliver \& Boyd.

RöGL, F. 1998a. The Styrian Basin. In Oligocene-Miocene foraminifera of the Central Parathetys (eds F. Rögl, C. Rupp \& J. Ctyroka), pp. 49-50. Abhandlungen der senckenbergischen naturforschenden Gesellschaft no. 549. Frankfurt am Main: Verlag Waldemar Kramer.

RÖGL, F. 1998b. Palaeogeographic Considerations for Mediterranean and Paratethys Seaways (Oligocene to Miocene). Annalen des Naturhistorischen Museums in Wien 99A, 279-310.

RÖGL, F. 1999. Mediterranean and Paratethys. Facts and hypotheses of an Oligocene to Miocene paleogeography (short overview). Geologica Carpathica 50(4), 33949.

RÖGL, F. \& STEININGER, F. F. 1983. Vom Zerfall der Tethys zu Mediterran und Paratethys. Die neogene Paläogeographie und Palinspastik des zirkummediterranen Raumes. Annalen des Naturhistorischen Museums in Wien 85A, 135-63.

RÖGL, F., Steininger, F. F. \& MÜller, C. 1978. Middle Miocene salinity crisis and paleogeography of the Paratethys (Middle and Eastern Europe). Initial Reports of the Deep Sea Drilling Project 42(1), 985-90.
RubAN, D. A. \& TYSZKA, J. 2005. Diversity dynamics and mass extinctions of the Early-Middle Jurassic foraminifera: A record from the Northwestern Caucasus. Palaeogeography, Palaeoclimatology, Palaeoecology 222, 329-43.

Schreilechner, M. G. \& SACHSEnhofer, R. F. 2007. High resolution sequence stratigraphy in the Eastern Styrian Basin (Miocene, Austria). Austrian Journal of Earth Science 100, 164-84.

Schütz, K., Harzhauser, M., RöGl, F., Ćorić, S. \& GALOVIC, I. 2007. Foraminiferen und Phytoplankton aus dem unteren Sarmatium des südlichen Wiener Beckens (Petronell, Niederösterreich). Jahrbuch der Geologischen Bundesanstalt 147, 449-88.

SchwalB, A., Burns, S. J. \& Kelts, K. 1999. Holocene environments from stable isotope stratigraphy of ostracods and authigenic carbonate in Chilean Altiplano Lakes. Palaeogeography, Palaeoclimatology, Palaeoecology 148, 153-68.

Steininger, F. F. \& Wessely, G. 2000. From the Tethyan Ocean to the Paratethys Sea: Oligocene to Neogene Stratigraphy, Paleogeography and Paleobiogeography of the circum-Mediterranean region and the Oligocene to Neogene Basin evolution in Austria. Mitteilungen der Österreichischen Geologischen Gesellschaft 92, 95116.

SUESS, E. 1866. Untersuchungen über den Charakter der österreichischen Tertiärablagerungen, II. Über die Bedeutung der sogenannten "brackischen Stufe" oder der "Cerithienschichten". Sitzungsberichte der kaiserlichen Akademie der Wissenschaften 54, 1-40.

TAKesue, R. K. \& VAN GeEN, A. 2004. Mg/Ca, Sr/Ca, and stable isotopes in modern and Holocene Protothaca staminea shells from a northern California coastal upwelling region. Geochimica et Cosmochimica Acta 68, 3845-61.

То́тн, Е. 2008. Sarmatian (Middle Miocene) ostracod fauna from the Zsámbék Basin, Hungary. Geologica Pannonica 36, 101-51.

TÜTKEn, T., Vennemann, T. W., JanZ, H. \& HeIZMANN, H. E. P. 2006. Palaeoenvironment and palaeoclimate of the Middle Miocene lake in the Steinheim basin, SW Germany, a reconstruction from $\mathrm{C}, \mathrm{O}$, and $\mathrm{Sr}$ isotopes of fossil remains. Palaeogeography, Palaeoclimatology, Palaeoecology 241, 457-91.

Vander Putten, E., Dehairs, F., Keppens, E. \& Baeyens, W. 2000. High resolution distribution of trace elements in the calcite shell layer of modern Mytilus edulis: Environmental and biological controls. Geochimica et Cosmochimica Acta 64, 997-1011.

Vrsaljko, D., PaVelić, D., Miknić, M., Brkić, M., KovÁčić, M., HećIMOVIĆ, I., HAJeK-TADESSE, V., AVAnić, R. \& KuRTANJEK, N. 2006. Middle Miocene (Upper Badenian/Sarmatian) palaeoecology and evolution of the environments in the area of Medvednica Mt. (North Croatia). Geologia Croatica 59, 51-63.

Zachos, J., Pagani, M., SlOAN, L., ThOMas, E. \& Billups, K. 2001. Trends, rhythms, and aberrations in global climate 65 Ma to present. Science 292, 686-93.

ZELENKA, J. 1990. A review of the Sarmatian Ostracoda of the Vienna Basin. In Ostracoda and Global Events (eds R. Whatley \& C. Maybury), pp. 263-70. London: British Micropalaeontological Society Publication, Chapman \& Hall. 